\title{
Performance of invasive species within marine reserves
}

\author{
Dana D. Burfeind ${ }^{1 *}$, Kylie A. Pitt ${ }^{1}$, Rod M. Connolly ${ }^{1}$, James E. Byers ${ }^{2}$ \\ ${ }^{1}$ Australian Rivers Institute - Estuaries and Coasts, and School of Environment, Griffith University, \\ Gold Coast Campus, Qld. 4222, Australia \\ ${ }^{2}$ Odum School of Ecology, University of Georgia, Athens, GA 30602, USA \\ * Corresponding author - (p) +617 5552 8324; (e) burfeind@uq.edu.au
}

Key Words: invasion resistance, marine protected area, marine reserve planning, diversity, disturbance, review

\begin{abstract}
Conservation of biodiversity is a major aim of marine reserves; however their effect on non-native invasive species, a major threat to biodiversity globally, is not widely known. Marine reserves could resist invasive species due to enhanced native diversity and biomass that heightens biotic resistance. Or invasive species could be enhanced by reserves by at least three mechanisms, including protection from harvesting, increased fishing pressure outside reserves facilitating invasions at a regional scale and increasing the exposure of reserves to more potential invaders, and increased propagule pressure from human visitation. We exhaustively searched the literature and found 13 cases that contained quantitative data on invasive species inside and outside marine reserves. In no cases did reserves resist invasive species. Of the seven cases where reserves were established prior to the arrival of the invasive species, five had no effect on the invasive species and two enhanced invasive species. Of the six cases where reserves were established in areas that had pre-existing invasive species, two had no effect on the invasive species and four enhanced the invasive species. These results suggest that while invasive species do equally well or better within marine reserves, too few data are currently available to draw broad, general conclusions regarding the effects of marine reserves on invasive species. Management plans for marine reserves rarely include guidelines for preventing or managing invasive species. If the trends we have detected here are supported by future studies, invasive species should be a priority for management of marine reserves.
\end{abstract}




\section{Introduction}

In terrestrial reserves invasive species have long been documented, absorbing substantial portions of management budgets for control and prevention efforts (Usher 1988; Westman 1990; Pimentel et al. 2005; Allen et al 2009). In the marine environment, reserves have only recently become a favored management option for conservation (Lubchenco et al. 2003). Like their terrestrial counterparts, marine reserves can effectively protect ecosystems from the effects of harvesting, but their ability to protect against other threats, such as pollution and invasive species, may be more limited (Simberloff 2000). In fact, marine invasive species are abundant (Bax et al. 2003); however, few studies (e.g. Simberloff 2000; Byers 2005; Klinger et al. 2006; Kellner and Hastings 2009) have discussed the extent or potential consequences of invasive species in marine reserves.

There are several mechanisms by which marine reserves could affect invasive species that lead to opposing predictions of their overall influence (Fig. 1). On one hand, marine reserves may limit invasive species. Marine reserves usually support a greater number of species than non-protected areas (Lester et al. 2009) and the higher biomass and species diversity within a reserve may limit the successful establishment and proliferation of invasive species whose success often stems from unused resources (Davis et al. 2000; Stachowicz et al. 2002). For example, at least at small spatial scales (settlement tiles), species-rich communities sometimes appear to withstand the establishment of invasive species (Fig. 1; Elton 1958; Stachowicz et al. 1999, 2002), leading to speculation that reserves may better resist invasion by nonnative species (Kellner and Hastings 2009). However, the hypothesis that species richness confers "invasion resistance" is often not supported on larger spatial scales (Byers and Noonburg 2003; Stohlgren et al. 2003; Fridley et al. 2007), including marine reserves, which in some cases have been documented to contain greater densities of invasive species than non-protected areas (e.g. Byers 2005; Klinger et al. 2006). While it could be argued that the addition of a new species may increase local diversity, it has been found that the introduction of a new species does not compensate for loss of native biodiversity (although this finding may be scale-dependent; Worm et al. 2006).

On the other hand, marine reserves may enhance invasive species. Marine reserves, particularly those created to protect areas of natural beauty, can be a drawcard for tourists (Edgar et al. 2010). If they attract higher rates of visitation this could promote the introduction of invasive species through increased disturbance and vectors (e.g., boat anchors, SCUBA equipment, bilge water, hull fouling) and subsequent dispersal of propagules (Lonsdale 1999; Minchinton and Bertness 2003; West et al. 2007; Britton-Simmons and Abbott 2008; Clark and Johnston 2009). Additionally, unlike terrestrial protected areas, most marine reserves are not managed to control invasive species within their boundaries. For invasive species that are harvested (recreationally or commercially), marine reserves may, ironically, act as a refuge from harvesting, resulting in the invasive species being more prevalent inside, than outside, the reserve 
(Byers 2005; Klinger et al. 2006). Another mechanism that may lead to a greater performance of invaders in reserves is higher diversity and abundance of predators and parasites that reduce the dominance and competitive abilities of potential native competitors (predator mediated competition; Liu and Stiling 2006). Additionally, it has been hypothesized that protection from fishing may facilitate the establishment of invasive species within a region by creating conditions for invasive species to establish (Kellner and Hastings 2009). By banning harvesting within reserves, fishing effort within the region is concentrated into smaller areas outside the reserve boundaries, increasing the fishing intensity per unit area (Byers and Noonburg 2007; Kellner and Hastings 2009). Concentrating fishing effort creates areas where densities of native species are reduced, which may increase the availability of resources and reduce interspecific competition (Kellner and Hastings 2009), creating an opportunity for non-native species to establish in a new region (Daskalov et al. 2007). Although inside the reserve the biomass at the highest tropic levels should remain intact maintaining biotic resistance, the presence of the reserve increases the ability of invasive species to establish at a regional level (Kellner and Hastings 2009). Additionally the reserves themselves may be more vulnerable compared to before the reserve was created because the establishment of new invasive species within a region may expose reserves to a greater abundance and diversity of potential invaders that are now established in the region (Kellner and Hastings 2009). This mechanism results in more invasive species overall in a region; however, at a smaller scale there would still likely be fewer invasive species inside reserves than outside due to stronger biotic resistance inside.

Finally, it is possible that marine reserves may have no effect on the persistence of invasive species. Many invasive species have dispersal mechanisms that would allow them to easily distribute across marine reserve boundaries, and if post-recruitment processes (e.g. predation, competition for resources or space) are not different between reserve and non-reserve locations, then there is unlikely to be a reserve effect.

In this study we conducted a systematic review of the literature to determine: 1) if marine reserves reduce, enhance or have no influence on the likelihood of successful colonization of invasive species; 2) if the implementation of a reserve affects the prevalence of existing invasive species. 


\section{Methods}

General approach

We systematically searched the peer-reviewed literature in ISI Web of Science (covering 1898 to June 2010). Articles returned by the searches were indexed according to the invasive species studied, the geographic location of the study, the year the species was first detected, the year the no-take reserve was established, the response variable measured (e.g. abundance, biomass), whether the invasive species is harvested, and the invasive species' performance in the reserve relative to control areas. We verified the location of the reserve, its no-take status, and the year it was established using the MPA Global database (Wood 2007). To be included in our analysis, studies needed to have quantitative measures of occurrence of the invasive species (e.g. abundance, relative abundance or biomass, ) inside and outside (i.e. in control areas) of one or more marine reserves. The marine reserves needed to be zoned as 'no-take' (i.e. all extractive activities prohibited) to be included. There was one exception where studies of intertidal bivalves and an alga from the San Juan Islands, USA, (Byers 2005; Klinger et al. 2006) were included even though limited degrees of fishing for salmon and herring were permitted (Klinger et al. 2006). The performance of a species within a marine reserve was categorized as:

- enhanced - invasive species that were more prevalent inside than outside reserves,

- resisted - species absent from, or less prevalent inside than outside reserves, or

- neutral - species that had similar patterns of occurrence, or showed no consistent pattern inside and outside reserves.

\section{Literature search strategies}

We first paired the search terms "introduced species", "invasive species", "NIS", "exotic", "non-native", "non-indigenous species", "nonindigenous species", "alien species", "introduction", and "foreign species" with every possible combination of "marine park", "marine protected area", "marine reserve", "no-take marine", and "MPA". This search produced 336 papers on invasive species in marine reserves, resulting in six case studies. We then searched by a combination of species name for the 15 most common invasive species mentioned in the first set of papers (Online Resource 1), and the previously mentioned five search terms for marine reserves. This search expanded on the previous search by capturing papers listing only species names, and not if a species was invasive in that area. This search identified an additional two case studies.

Studies of invasive species undertaken incidentally in marine reserves but without a focus on reserves were unlikely to have been identified using our previous search strategies. We therefore undertook a detailed geographic search of countries occurring in 11 key regions (Online Resource 2). We searched the International Union for 
Conservation of Nature (IUCN) Global Invasive Species Database for invasive marine species that occurred in each country within each of the 11 regions. If a country bordered more than one region (e.g. Canada was included in both the west and east coast of North America regions), then the appropriate state/province that occurred in each region was searched instead of the country. It was important to search countries bordering more than one region separately as different invasive species occur in each region (e.g. Spartina alterniflora is native on the east coast of North America, but invasive on the west coast). Then we searched each species and location combination within ISI Web of Science to determine the species/location combinations with the greatest number of publications. Species that returned more than 30 papers for that region were included in regional searches (4-7 species per region). In the Caribbean, South America, southeastern Africa, Asia, Australia, New Zealand and Hawai'i, all invasive species occurring in the IUCN Global Invasive Species Database for that region were used, as there were few invasive species with greater than 30 studies. Studies were then searched for quantitative data on the occurrence of invasive species at two or more locations, where at least one of the locations could have been a reserve. In suitable papers, we searched study locations in the MPA Global database to determine if studies took place within reserves. Where necessary, authors were contacted to verify if studies were conducted within no-take reserves. Pelagic species were excluded, as they are likely to have short residence times in reserves as adults. We identified a further five case studies with this search strategy.

Case studies were divided into two categories: 1) reserves that were established before the invasive species was introduced, and 2) reserves that were established in areas where invasive species were already detected. If statistical comparisons of the occurrence of invasive species inside and outside reserves were not reported, we extracted relevant data and tested for differences inside and outside reserves. The statistical analyses and evidence used to categorize the effect of the reserve on the invasive species for each case study are presented in Table 1 . Where statistical tests were possible but showed no significant difference inside and outside reserves, we calculated the statistical power of the test to detect differences. Power was calculated using $\mathrm{G}^{*}$ Power v3 with alpha set at 0.05 and the effect size calculated using the mean and standard deviation of each group. The effect sizes therefore reflected the differences between means inside and outside reserves found in the study as opposed to us setting a standard consistent across the studies. Thus, effect sizes varied among studies, but were typically large (e.g. mean inside reserve $>25 \%$ different to outside; Online Resource 3). Two case studies (H. stipulacea from St. Lucia and Dominica) only had one reserve and one non-reserve location and therefore did not have enough data for formal statistical analysis (see Table 1). Our search revealed only 13 studies that met our strict criteria. A formal meta-analysis was not, therefore, possible but trends in the data were described. 
Results

Our search through more than 13000 papers found 13 cases from 8 papers containing quantitative data on invasive species inside and outside marine reserves. In no cases did reserves resist invasive species. Where reserves were established before the invasive species was introduced, there were five cases where reserves exhibited neutral effects on invasive species and two cases where reserves enhanced invasive species (Table 2). The first of these latter two cases was the sponge Chalinula nematifera which, in a survey of 150 locations ( 9 reserve and 141 non-reserve) along the west coast of Mexico, occurred only in two reserves and none of the 141 nonreserve locations (Avila and Carballo 2009). The second case was the alga Undaria pinnatifida in Tinderbox Reserve in Tasmania, Australia, where the alga had an average of $10 \%$ cover in spring 2001 (the first year the species was detected in the area) but was absent in 2 adjacent control sites (Barrett et al. 2009). For marine reserves that were established after an invasive species had been established, there were two cases where marine reserves had neutral effects on invasive species and four cases where marine reserves enhanced invasive species (Table 3). Of the four cases where marine reserves enhanced invasive species, two of these species were harvested (both bivalves, Crassostera gigas and Venerupis philippinarum) and two were not harvested (the barnacle Elminius modestus and the alga Sargassum muticum).

Estimates of statistical power in neutral cases established that power of tests to detect differences inside and outside reserves was low (all values $<0.32$; Table 1 ); this low power, even at relatively large effect sizes, reflects the small sample size used in many tests of reserve effects. 


\section{Discussion}

Our results must be interpreted cautiously because of the limited sample size, but they do indicate that marine reserves do not resist invasive species, nor does the implementation of a reserve reduce the persistence of existing invasive species. Indeed reserves appear to have little influence on invasive species as seven of the 13 cases showed no effect of protection. In all cases, however, the statistical power to detect a difference, should one have existed, was low. In areas where reserves were established after the invasive species was introduced, there were more cases where the invasive species performed better within reserves. This observation applied to some species that were harvested (Crassostrea gigas, Venerupis phillppinarum) and, therefore, benefited from the cessation of harvesting once the marine reserve was established (Byers 2005; Klinger et al. 2006). Two of the other positively influenced species (S. muticum and E. modestus) are not harvested themselves, but likely benefited by commonly living as epibionts on the harvested non-native oyster $C$. gigas (Klinger et al. 2006; Witte et al. 2010). The other species that were positively affected presumably benefited because many species generally perform better within marine reserves (Lester et al. 2009), and the same factors promoting the abundance of native species might also have aided the invasive species.

The limited studies available suggest that invasive species are often abundant and cooccur with other invasive species inside reserves (Byers 2005; Klinger et al. 2006; Abdulla et al. 2008). Indeed, even isolated or reasonably pristine reserves hosted multiple invasive species (PMNM 2008). It is important to acknowledge that there is often spatial and taxonomic bias in reporting the occurrence of invasive species (Ruiz et al. 2000); therefore, given that many marine reserves are the subjects of research it may be more likely that there are a higher number of invasive species reported in marine reserves than unprotected areas. However, any such bias would most likely affect data on the occurrence or presence/absence of invaders as opposed to the pairwise comparisons of the relative performance of invasive species inside versus outside of reserves that we focused on here. From a conservation perspective what remains as a potentially troubling issue is that the presence of invasive species may facilitate the colonization of subsequent invasive species (i.e. invasion meltdown; Simberloff and Von Holle 1999). Because a primary goal of many marine reserves is to maintain high biodiversity, their conservation value is potentially undermined since invasive species may ultimately reduce biodiversity (Carlton 1999; Bax et al. 2003).

Any relationship between reserve status and invasion success may be very complex. This relationship is likely to be a function of the attributes of the reserve (e.g. habitat, location, size, and age of the reserve) and the dynamics within the reserve (e.g. condition of the native community, disturbance regime, magnitude of invasion pressure). However, we need a much larger data set than is currently available to tease out the impact of each of these factors. 
Even with our exhaustive review, we found very few empirical comparisons of invasive species between marine reserves and appropriate control areas. Additionally, of the 13 case studies included in this paper there were six different response variables measured: percent cover (4 case studies), biomass (2), CPUE (2), density (2), average maximum abundance (1), and presence/absence (1). The most rigorous approach to testing our hypothesis would be to undertake a formal meta-analysis but the paucity of data and the diversity of response variables measured in the case studies made a formal meta-analysis impracticable (see Harrison 2011). There were only two studies representing five case studies (Byers 2005; Klinger et al. 2006), of the 13000 we searched, that explicitly examined the role of marine reserves on invasive species, which serves to highlight a critical need for more research on invasive species in marine reserves. It is also worth noting that there was a non-random geographic distribution of the case studies that we found. There were no case studies from Africa, South America, or Asia. While invasive species are identified in these regions, and marine reserves are present, there were fewer studies to interrogate from these regions.

Control, detection, and eradication of invasive species are a common priority issue for management of terrestrial reserves (Thomas 1988; Usher 1988; Macdonald et al. 1989; Westman 1990). For example, $>3700$ non-native plant species have been catalogued within US National Parks (Allen et al. 2009). However, in the marine realm, non-native species have received little attention in reserve planning processes. In some marine reserves the occurrence of invasive species has been quantified (deRivera et al. 2005; Abdulla et al. 2008) yet these studies have not led to substantive changes to the ways in which those reserves are managed. Indeed, the role of invasive species (Simberloff 2000) and potential consequences to the effectiveness of marine reserves in maintaining biodiversity (Kellner and Hastings 2009) are rarely considered in reserve planning. While there has been some discussion among scientists of incorporating management of invasive species into management plans for marine reserves (Wasson et al. 2002), there are very few practical examples of this being done. The management plan for Papahānaumokuākea Marine National Monument in Hawai'i (PMNM 2008) is unique in its comprehensive management strategies for invasive species. For example, they have implemented strict quarantine and inspection protocols for vessels and equipment entering the marine reserve. Furthermore, they have developed an invasive species action plan to detect, control, and eradicate (where possible) invasive species occurring within the marine reserve. We acknowledge that the reserve's extreme isolation $(200 \mathrm{~km}$ from the nearest populated island, Kaua'i) may create a unique opportunity to incorporate strict vessel and gear inspection. However, it is important that all reserves incorporate strategies to limit the introduction of invasive species and manage existing invasive species as part of the reserve planning process.

In summary, it is surprising how little is known about the extent and performance of invasive species in marine reserves compared to their terrestrial counterparts. We 
encourage scientists to undertake quantitative and rigorous studies of invasive species by sampling invasive species inside marine reserves and at appropriate control areas, and replicating their studies through time. If the trend of marine reserves exerting positive effects on invasive species continues to be supported by future studies, invasive species should be a priority for management of marine reserves, much as they already are in terrestrial reserves.

Acknowledgments

We thank the many authors we contacted for providing additional information. Funding was provided by an Australian Research Council Grant (LP0989796) to R.M.C. and K.A.P. We would also like to acknowledge the anonymous reviewers for their comments, which improved the quality of this paper. 


\section{Literature Cited}

Abdulla A, Gomei M, Maison E, Piante C (2008) Status of marine protected areas in the Mediterranean Sea. IUCN, Malaga and WWF, France

Allen JA, Brown CS, Stohlgren TJ (2009) Non-native plant invasions of the United States National Parks. Biol Invasions 11:2195-2207

Avila E, Carballo JL (2009) A preliminary assessment of the invasiveness of the IndoPacific sponge Chalinula nematifera on coral communities from the tropical Eastern Pacific. Biol Invasions 11:257-264

Barrett NS, Buxton CD, Edgar GJ (2009) Changes in invertebrate and macroalgal populations in Tasmanian marine reserves in the decade following protection. J Exp Mar Biol Ecol 370:104-119

Bax N, Williamson A, Aguero M, Gonzalez E, Geeves W (2003) Marine invasive alien species: a threat to global biodiversity. Mar Policy 27:313-323

Britton-Simmons KH, Abbott KC (2008) Short- and long-term effects of disturbance and propagule pressure on a biological invasion. Journal of Ecology 96:68-77

Byers JE (2005) Marine reserves enhance abundance but not competitive impacts of a harvested nonindigenous species. Ecology 86:487-500

Byers JE, Noonburg (2003) Scale dependent effects of biotic resistance to biological invasion. Ecology 84:1428-1433

Byers JE, Noonburg (2007) Poaching, enforcement, and the efficacy of marine reserves. Ecol App 17:1851-1856

Clark GF, Johnson EL (2009) Propagule pressure and disturbance interact to overcome biotic resistance of marine invertebrate communities. Oikos 118:1679-1689

Carlton JT (1999) Scale and ecological consequences of biological invasions in the world's oceans. In Sandlund OT, Schei PJ, and Viken A (eds) Invasive species and biodiversity management. Kluwer Academic Publishers, Dordrecht, The Netherlands. pp 195-212

Daskalov GM, Grishin AN, Rodionov S, Mihneva V (2007) Trophic cascades triggered by overfishing reveal possible mechanisms of ecosystem regime shifts. PNAS 104: 10518-10523

Davis MA, Grime JP, Thompson K (2000) Fluctuating resources in plant communities: a general theory of invasibility. J Ecol 88: 528-534

deRivera CE, Ruiz GM, Crooks JA, Wasson K, Lonhart SI, Fofonoff P, Steves BP, Rumrill SS, Brancato MS, Pegau WS, Bulthuis DA, Preisler RK, Schooch GC, Browlby E, DeVogelaere A, Crawford MK, Gittings SR, Hines AH, Takata L, Larson K, Huber T, Leyman AM, Collinetti E, Pasco T, Shull S, Anderson M, Powell S (2005) Broad-scale non-indigenous species monitoring along the west coast in national marine sanctuaries and national estuarine research reserves. Aquatic Invasions Institute, Portland, Oregon

Edgar GJ, Last PR, Barrett NS, Gowlett-Holmes K, Driessen M, Mooney P (2010) Conservation of natural wilderness values in the Port Davey marine and estuarine protected area, south-western Tasmania. Aquatic ConservationMarine Freshw Eco 20:297-311 
Elton CS (1958) The ecology of invasion by animals and plants. Methuen, London Grosholz ED, Ruiz GM (1995) Spread and potential impact of the recently introduced European green crab, Carcinus maenas, in central California. Mar Biol 122:239-247

Fridley JD, Stachowicz JJ, Naeem S, Sax DF, Seabloom EW, Smith MD, Stohlgren TJ, Tilman D, Von Holle B (2007) The invasion paradox: reconciling pattern and process in species invasions. Ecology 88:3-17

Harrison F (2011) Getting started with meta-analysis. Meth Ecol Evol. 2:1-10

Halpern BS (2003) The impact of marine reserves: Do reserves work and does reserve size matter? Ecol App 13(1):S117-S137

Kellner JB, Hastings A (2009) A reserve paradox: introduced heterogeneity may increase regional invasability. Conservation Letters 2:115-122

Klinger T, Padilla DK, Britton-Simmons K (2006) Two invaders achieve higher densities in reserves. Aquat Conserv-Mar Freshw Eco 16:301-311

Lawson J, Davenport J, Whitaker A (2004) Barnacle distribution in Lough Hyne Marine Nature Reserve: A new baseline and an account of invasion by the introduced Australasian species Elminius modestus Darwin. Est Coast Shelf Sci 60:729-735

Lester SE, Halpern BS, Grorud-Colvert K, Lubchenco J, Ruttenberg BI, Gaines SD, Airame S, Warner RR (2009) Biological effects within no-take marine reserves: A global synthesis. Mar Ecol Prog Ser 384:33-46

Liu H, Stiling P (2006) Testing the enemy release hypothesis: a review and metaanalysis. Biol Invasions (7):1535-1545

Lonsdale WM (1999) Global patterns of plant invasions and the concept of invasibility. Ecology 80: 1522-1536

Lubchenco J, Palumbi SR, Gaines SD, Andelman S (2003) Plugging a hole in the ocean: The emerging science of marine reserves. Ecol App 13:S3-S7

Macdonald IAW, Loope LL, Usher MB, Hamann O (1989) Wildlife conservation and the invasion of nature reserves by introduced species: a global perspective. In Drake JA, Mooney HA, di Castri F, Groves RH, Kruger EJ, Rejmanek M, Williamson M (eds) Biological invasions: a global perspective. Scope 37. John Wiley and Sons, Chichester, England pp 215-256

Minchinton TE, Bertness MD (2003) Disturbance-mediated competition and the spread of Phragmites australis in a coastal marsh. Ecological Applications 13:1400-1416

Papahānaumokuākea Marine National Monument (PMNM) (2008) Papahānaumokuākea Marine National Monument managment plan. Papahānaumokuākea Marine National Monument, Honolulu, Hawai'i

Pimentel D, Zuniga R, Morrison D (2005) Update on the environmental and economic costs associated with alien-invasive species in the United States. Ecol Econ 52: $273-288$

Ruiz GM, Fofonoff PW, Carlton JT, Wonham MJ, Hines AH (2000) Invasion of coastal marine communities in North America: Apparent patterns, processes, and biases. Annu Rev Ecol Syst 31:481-531 
Simberloff D (2000) No reserve is an island: Marine reserves and nonindigenous species. Bull Mar Sci 66:567-580

Simberloff D, Von Holle B (1999) Positive interactions of nonindigenous species: invasional meltdown? Biol Invasions 1:21-32

Stachowicz JJ, Fried H, Osman RW, Whitlatch RB (2002) Biodiversity, invasion resistance, and marine ecosystem function: reconciling pattern and process. Ecology 83:2575-2590

Stachowicz JJ, Whitlatch RB, Osman RW (1999) Species diversity and invasion resistance in a marine ecosystem. Science 286:1577-1579

Stohlgren TJ, Barnett DT, Kartesz JT (2003) The rich get richer: patterns of plant invasions in the United States 1:11-14

Steiner SC, Willette DA (2010) Distribution and size of benthic marine habitats in Dominica, Lesser Antilles. Rev Biol Tropo 58:589-602

Thomas LK (1988) Management of exotic species in natural communities. Conference on science in the National Parks, Volume 5. The George Wright Society and the USDA National Park Service, Ft. Collins, Colorado, USA

Thresher R, Proctor C, Ruiz G, Gurney R, MacKinnon C, Walton W, Rodriguez L, Bax N (2003) Invasion dynamics of the European shore crab, Carcinus maenas, in Australia. Marine Biology 142:867-876

Usher MB (1988) Biological invasions of nature reserves: A search for generalisations. Biol Consv 44:119-135

Wasson K, Lohrer D, Crawforf M, Rumrill S (2002) Non-native species in our nation's estuaries: a framework for an invasion monitoring program, National Esturine Research Reserve Technical Report Series 2002:1

West EJ, Barnes P, Wright J, Davis A (2007) Anchors aweigh: Fragment generation of invasive Caulerpa taxifolia by boat anchors and its resistance to desiccation. Aquat Bot 87:196-202

Westman WE (1990) Park management of exotic plant species: problems and issues. Cons Biol 4:251-260

Willette DA, Ambrose RF (2009) The distribution and expansion of the invasive seagrass Halophila stipulacea in Dominica, West Indies, with a preliminary report from St. Lucia. Aquat Bot 91:137-142

Witte S, Buschbaum C, van Beusekom JEE, Reise K (2010) Does climatic warming explain why an introduced barnacle finally takes over after a lag of more than 50 years? Biol Invasions 12:3579-3589

Wood LJ (2007) MPA Global: A database of the world's marine protected areas. Sea Around Us Project, UNEP-WCMC \& WWF. Available from www.mpaglobal.org (accessed August 2010)

Worm B, Barbier EB, Beaumont N, Duffy E, Folke C, Halpern BS, Jackson JBC, Lotze HK, Micheli F, Palumbi SR, Sala E, Selkoe KA, Stachowicz JJ, Watson $\mathrm{R}$ (2006) Impacts of biodiversity loss on ocean ecosystem serivces. Science $314: 787-790$ 
Invasive species in marine reserves 
Invasive species in marine reserves

Figure Legend

Figure 1. Theoretical pathways by which marine reserves resist or enhance invasive species. 
Figure 1.

\section{Establish marine reserve}

Increases biodiversity and biomass

Increases competition for space and resources

Protect against invasion
Enhance invasion success
Concentrates fishing Increases effort in areas outside predators \& reserve parasites

Reduces competition for space \& resources

Facilitates regional introductions

Decreases competition from native species

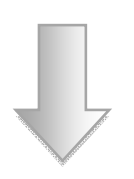

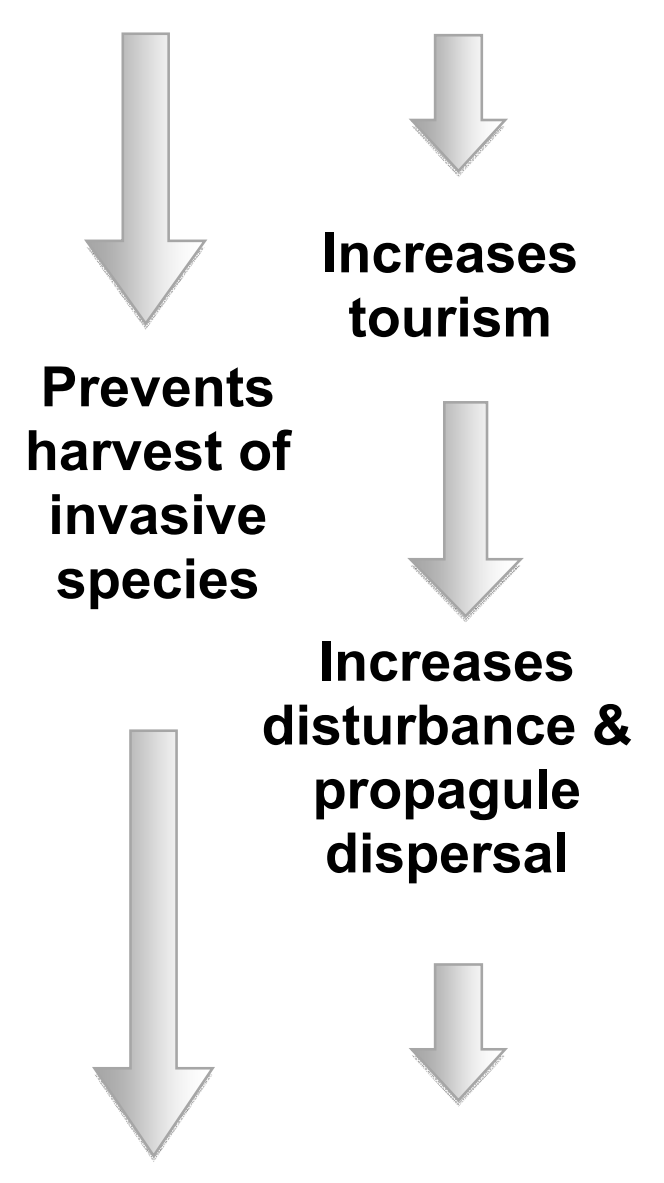

Increases tourism

Prevents harvest of invasive species disturbance \& propagule dispersal 
Table 1: Summary of analyses used to determine performance of invasive species in marine reserves. Effect size is calculated from the differences in the means and standard deviations in control and reserve locations, as determined using G*Power. Performance in reserves is defined as: Resisted (-); Neutral (0); Enhanced (+).

\begin{tabular}{|c|c|c|c|c|c|}
\hline $\begin{array}{l}\text { Performance } \\
\text { in reserve }\end{array}$ & Species & Reserve Location & Objective & Test of effect & Reference \\
\hline- & none & & & & \\
\hline 0 & $\begin{array}{l}\text { Carcinus } \\
\text { maenas (crab) }\end{array}$ & $\begin{array}{l}\text { Maria Island - } \\
\text { Tasmania, } \\
\text { Australia }\end{array}$ & $\begin{array}{l}\text { To compare CPUE of } \\
\text { C. maenas in several } \\
\text { locations along the } \\
\text { east coast of } \\
\text { Tasmania, South } \\
\text { Australia, Victoria, } \\
\text { and southern New } \\
\text { South Wales. }\end{array}$ & $\begin{array}{l}\text { Since both reserve and control locations } \\
\text { were present only in Tasmania, only data } \\
\text { from Tasmania were analyzed ( } 1 \text { reserve } \\
\text { and } 10 \text { control locations (excluding } \\
\text { Hobart area)). } 1 \text {-sample t-test, } p=0.240 \text {, } \\
\text { Power }=0.32 \text {, Effect size }=0.40\end{array}$ & Thresher et al. 2003 \\
\hline 0 & $\begin{array}{l}\text { Carcinus } \\
\text { maenas (crab) }\end{array}$ & $\begin{array}{l}\text { Redwood Shores } \\
\text { and Elkhorn } \\
\text { Slough - } \\
\text { California, USA }\end{array}$ & $\begin{array}{l}\text { To compare } C \text {. } \\
\text { maenas CPUE along } \\
\text { the coast of } \\
\text { California (northern } \\
\text { to central California). }\end{array}$ & $\begin{array}{l}\text { Two reserves and } 9 \text { control locations were } \\
\text { surveyed. t-test, } p=0.587 \text {, Power }=0.06 \text {, } \\
\text { Effect size }=0.04\end{array}$ & Grosholz \& Ruiz 1995 \\
\hline 0 & $\begin{array}{l}\text { Halophila } \\
\text { stipulacea } \\
\text { (seagrass) }\end{array}$ & $\begin{array}{l}\text { Cabritas National } \\
\text { Park - Dominica }\end{array}$ & $\begin{array}{l}\text { To map distributions } \\
\text { of invasive seagrass } \\
\text { and other habitats. }\end{array}$ & $\begin{array}{l}\text { Percentage covers in the reserve }(20 \%) \text {, } \\
\text { and control site }(22 \%) \text { were similar but } \\
\text { since only one data point was available for } \\
\text { the marine reserve and control, no } \\
\text { statistical analysis was undertaken. }\end{array}$ & $\begin{array}{l}\text { Willette \& Ambrose 2009, } \\
\text { Steiner \& Willette } 2010\end{array}$ \\
\hline
\end{tabular}




$\begin{array}{ll}\text { Halophila } & \text { Anse la Raye } \\ \text { stipulacea } & \text { Marine Reserve } \\ \text { (seagrass) } & \text { Management } \\ & \text { Area - St Lucia }\end{array}$

Nuttallia

obscurata

(bivalve)

Mya arenaria

(bivalve)

0

Area - St Lucia

Argyle Lagoon,

British Camp

Historical Site

and Shaw Island

- San Juan

Islands,

Washington,

USA

USA

Undaria

Maria Istand,
To map distributions

of invasive seagrass.
Argyle Lagoon, To compare the
British Camp density and biomass
Historical Site
and Shaw Island
- San Juan
Islands,
Washington,
of 4 species of
bivalves ( 3 invasive,
1 native) at 3 reserves
and 11 control sites. density and biomass bivalves ( 3 invasive, at 3 reserves and 11 control sites. t-test, $\mathrm{p}=0.318$, Power $=0.18$, Effect size $\quad$ Byers 2005

$=0.53$

t-test, $\mathrm{p}=0.744$, Power $=0.09$, Effect size

$=0.23$

Willette \& Ambrose 2009

occurring very recently and the small total area covered by the seagrass, the reserve was determined to have had no effect on the invasion.

Byers 2005

(1)

To compare fish and

The analysis was based on mean percent

Barrett et al. 2009 
pinnatifida

(alga)

\section{Chalinula \\ nematifera \\ (sponge)}

Crassostera
gigas
(bivalve)

Elminius

modestus

(barnacle)
Tasmania,

Australia

Isla Isabel

National Park

and Cabo Pulmo

- Mexico

Point Caution,
Argyle Lagoon
and False Bay -

San Juan Islands,

USA

Lough Hyne

Marine Nature

Objective: to

compare the

Reserve - Ireland

abundance and

vertical distribution

141 non-reserves)

along the west coast

of Mexico for the

invasive sponge

Chalinula.

of $C$. gigas at 3 cover (values were extracted from figures)

of $U$. pinnatifida averaged across 6

replicate sampling sites within Maria

Island Reserve and at 6 control sites

outside reserve. Test compared average $\%$

cover inside vs outside reserves over 6

years. t-test, $\mathrm{p}=0.497$, Power $=0.12$,

Effect size $=0.30$

Test of effect: The sponge occurred in 2

Avila \& Carballo 2009

locations (9 reserves,

To compare densities ANOVA, $\mathrm{p}=0.05$

reserves and 5 control

of the 150 locations and both were within

reserves. The probability of the sponge

occurring within the two reserves by

chance was calculated as follows: $(9 \mathrm{x}$

$150) \times(8 \times 149) \rightarrow p=0.0097$.

Klinger et al. 2006

Test of effect: Average of maximum

Lawson et al. 2004 abundance of $E$. modestus inside reserves was 1800 barnacles $\mathrm{m}^{-2}$, compared with 75 barnacles $\mathrm{m}^{-2}$ in control sites. 


\begin{tabular}{|c|c|c|c|c|c|}
\hline & & & $\begin{array}{l}\text { of multiple species of } \\
\text { barnacle at } 11 \text { sites } \\
\text { within the marine } \\
\text { reserve and } 6 \text { sites } \\
\text { outside the reserve. }\end{array}$ & & \\
\hline+ & $\begin{array}{l}\text { Sargassum } \\
\text { muticum } \\
\text { (alga) }\end{array}$ & $\begin{array}{l}\text { Point Caution, } \\
\text { Point George, } \\
\text { Yellow Island, } \\
\text { Low Island, } \\
\text { Argyle Lagoon } \\
\text { and False Bay - } \\
\text { San Juan Islands, } \\
\text { USA }\end{array}$ & $\begin{array}{l}\text { To compare } \\
\text { abundances of } S . \\
\text { muticum in } 4 \text { reserves } \\
\text { and } 10 \text { control sites. }\end{array}$ & ANOVA, $p=0.05$ & Klinger et al. 2006 \\
\hline+ & $\begin{array}{l}\text { Undaria } \\
\text { pinnatifida } \\
\text { (alga) }\end{array}$ & $\begin{array}{l}\text { Tinderbox - } \\
\text { Tasmania, } \\
\text { Australia }\end{array}$ & $\begin{array}{l}\text { To compare fish and } \\
\text { macroalgal } \\
\text { communities inside } \\
\text { versus outside } \\
\text { marine reserves in } \\
\text { Tasmania, Australia }\end{array}$ & $\begin{array}{l}\text { Although } U \text {. pinnatifida has been present } \\
\text { in Tasmania since } 1988 \text {, it did not occur in } \\
\text { Tinderbox Reserve or nearby control areas } \\
\text { until spring } 2001 \text {. Therefore, Tinderbox } \\
\text { Reserve was analyzed as a separate case } \\
\text { study (from Maria Island) as the reserve } \\
\text { was established before the species was } \\
\text { introduced. Average } 10 \% \text { cover at } 2 \\
\text { locations in reserve, absent at } 2 \text { control } \\
\text { locations. Insufficient data available for a } \\
\text { statistical test. }\end{array}$ & Barrett et al. 2009 \\
\hline+ & $\begin{array}{l}\text { Venerupis } \\
\text { philippinarum }\end{array}$ & $\begin{array}{l}\text { Argyle Lagoon, } \\
\text { British Camp }\end{array}$ & $\begin{array}{l}\text { Objective: to } \\
\text { compare the density }\end{array}$ & $\begin{array}{l}\text { Test of effect: density (t-test, } \mathrm{p}=0.0085) \\
\text { and biomass }(\mathrm{t}=-3.43, \mathrm{p}=0.0075)\end{array}$ & Byers 2005 \\
\hline
\end{tabular}


(bivalve) Historical Site and biomass of 4

and Shaw Island species of bivalves ( 3

- San Juan invasive, 1 native) at

Islands, 3 reserves and 11

Washington, control sites

USA 
Table 2. Performance of invasive species in marine reserves, where reserves were established before the invasive species were introduced. Resisted (-); Neutral (0); Enhanced (+)

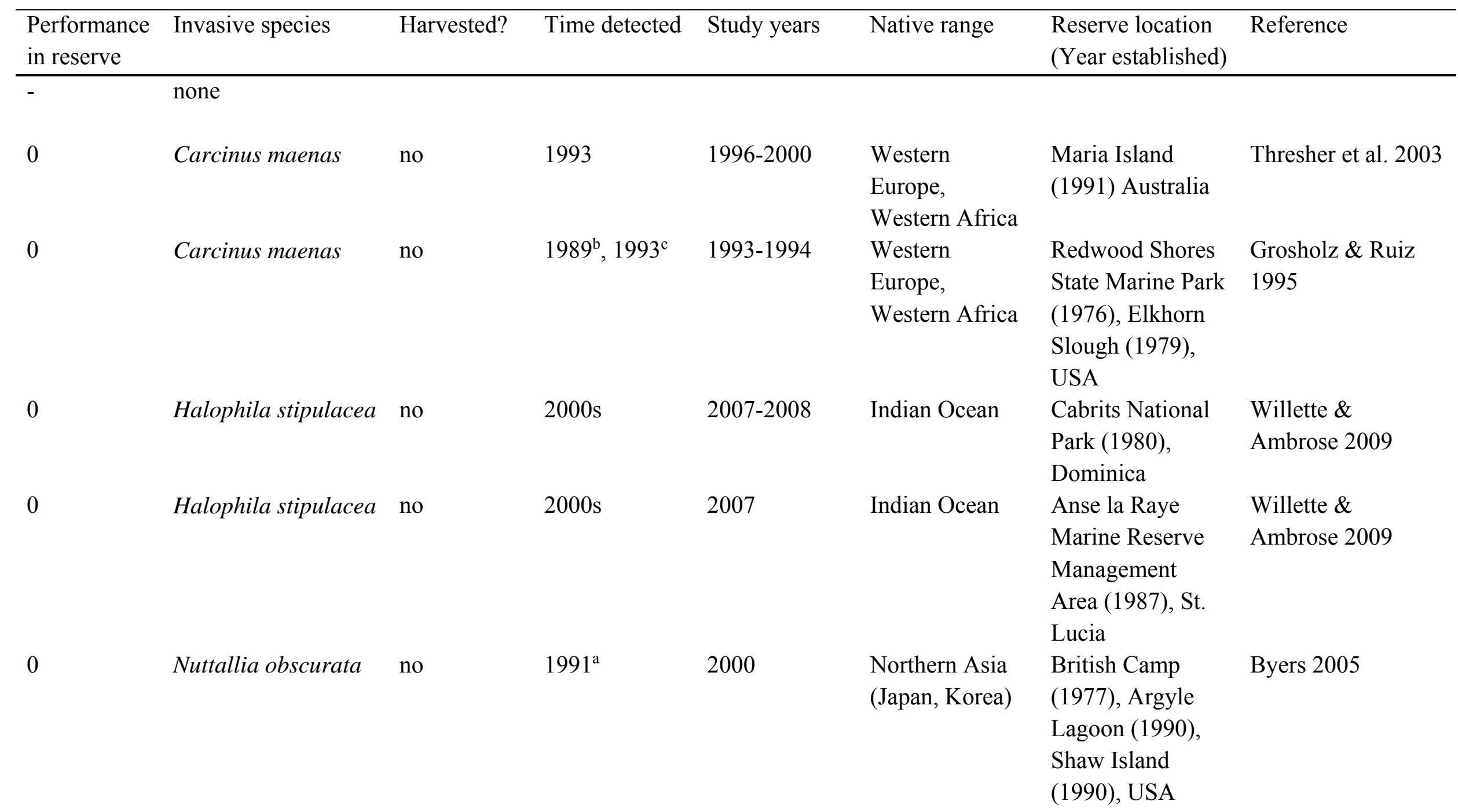




\begin{tabular}{|c|c|c|c|c|c|c|c|}
\hline+ & $\begin{array}{l}\text { Chalinula } \\
\text { nematifera }\end{array}$ & no & 2003 & 1999-2007 & Indo-Pacific & $\begin{array}{l}\text { Isla Isabel } \\
\text { National Park } \\
\text { (1980), } \\
\text { Cabo Pulmo } \\
\text { (1995), Mexico }\end{array}$ & $\begin{array}{l}\text { Avila \& Caballo } \\
2009\end{array}$ \\
\hline+ & Undaria pinnatifida & $\begin{array}{l}\text { not in this } \\
\text { region }\end{array}$ & 2001 & 1992-2002 & $\begin{array}{l}\text { Eastern Asia } \\
\text { (Japan, China, } \\
\text { Korea) }\end{array}$ & $\begin{array}{l}\text { Tinderbox (1991), } \\
\text { USA }\end{array}$ & Barrett et al. 2009 \\
\hline
\end{tabular}

${ }^{\text {a}}$ First report from Pacific Northwest, on Vancouver Island. Anecdotally reported in San Juan Islands between 1996-1998.

${ }^{b}$ First report from San Francisco Bay

${ }^{\mathrm{c}}$ First report from Monterey Bay 
Table 3. Performance in marine reserves, where marine reserves were established after the invasive species were introduced. Resisted (-); Neutral (0); Enhanced (+)

\begin{tabular}{|c|c|c|c|c|c|c|c|}
\hline $\begin{array}{l}\text { Performance } \\
\text { in reserve }\end{array}$ & Invasive species & Harvested? & Year detected & Study years & Native range & $\begin{array}{l}\text { Reserve } \\
\text { location } \\
\text { (Year } \\
\text { established) }\end{array}$ & Reference \\
\hline- & none & & & & & & \\
\hline 0 & Mya arenaria & $\begin{array}{l}\text { not in this } \\
\text { region }\end{array}$ & late $1800 \mathrm{~s}$ & 2000 & $\begin{array}{l}\text { Atlantic coast } \\
\text { North America }\end{array}$ & $\begin{array}{l}\text { British Camp } \\
\text { Historical Site } \\
\text { (1977), Argyle } \\
\text { Lagoon (1990), } \\
\text { Shaw Island } \\
\text { (1990), USA }\end{array}$ & Byers 2005 \\
\hline 0 & Undaria pinnatifida & $\begin{array}{l}\text { not in this } \\
\text { region }\end{array}$ & 1988 & 1992-2002 & $\begin{array}{l}\text { Eastern Asia } \\
\text { (Japan, China, } \\
\text { Korea) }\end{array}$ & $\begin{array}{l}\text { Maria Island } \\
(1991), \\
\text { Australia }\end{array}$ & Barrett et al. 2009 \\
\hline+ & Crassostera gigas & yes & early 1900s & 2001 & Japan & $\begin{array}{l}\text { Point Caution, } \\
\text { Argyle Lagoon, } \\
\text { False Bay } \\
\text { (1990), USA }\end{array}$ & Klinger et al 2006 \\
\hline+ & Elminius modestus & no & 1956 & 2001 & $\begin{array}{l}\text { New Zealand, } \\
\text { southern } \\
\text { Australia }\end{array}$ & $\begin{array}{l}\text { Lough Hyne } \\
\text { Marine Nature } \\
\text { Reserve (1981), }\end{array}$ & Lawson et al. 2004 \\
\hline
\end{tabular}


Invasive species in marine reserves

Ireland

\begin{tabular}{|c|c|c|c|c|c|c|c|}
\hline+ & Sargassum muticum & no & late $1800 \mathrm{~s}$ & 2002 & $\begin{array}{l}\text { Eastern Asia } \\
\text { (Japan, China, } \\
\text { Korea) }\end{array}$ & $\begin{array}{l}\text { Point Caution, } \\
\text { Point George, } \\
\text { Yellow Island, } \\
\text { Low Island, } \\
\text { Argyle Lagoon, } \\
\text { False Bay } \\
\text { (1990), USA }\end{array}$ & Klinger et al. 2006 \\
\hline+ & $\begin{array}{l}\text { Venerupis } \\
\text { phillppinarum }\end{array}$ & yes & $1930 \mathrm{~s}$ & 2000 & Japan & $\begin{array}{l}\text { British Camp } \\
\text { Historical Site } \\
\text { (1977), Argyle } \\
\text { Lagoon (1990), } \\
\text { Shaw Island } \\
\text { (1990), USA }\end{array}$ & Byers 2005 \\
\hline
\end{tabular}


Online Resource 1 - Species used in taxonomic search

Common name

Asian date mussel

Asian mitten crab

European green crab

Fan worm

Feather algae

Grape algae

Halophila seagrass

Japanese kelp

New Zealand screwshell

North Pacific sea star

Pacific lionfish

Pacific oyster

Strap weed

Venus clam

Wire weed
Scientific name

Musculista senhousia

Eriocheir sinensis

Carcinus maenas

Euchore limnicola

Caulerpa taxifolia

Caulerpa racemosa

Halophila stipulacea

Undaria pinnatifida

Maoricolpus roseus

Asterias amurensis

Pterois volitans

Crassostrea gigas

Caulerpa filiformis

Ruditapes largillierti

Sargassum muticum 
Online Resource 2 - Geographic search terms

North America - West Coast

Location search terms

Invasive species search terms

\begin{tabular}{ll}
\hline Alaska & Carcinus maenas \\
Baja California & Caulerpa taxifolia \\
British Columbia & Crassostrea gigas \\
California & Mytilus galloprovincialis \\
Oregon & Spartina alterniflora \\
Washington & Undaria pinnatifida \\
& Zostera japonica
\end{tabular}

North America - East Coast

Location search terms

Invasive species search terms

\begin{tabular}{ll}
\hline Alabama & $\begin{array}{l}\text { Carcinus maenas } \\
\text { Campeche }\end{array}$ \\
Connecticut & $\begin{array}{l}\text { Perna perna } \\
\text { Pterois volitans }\end{array}$ \\
Delaware & \\
Florida & \\
Georgia & \\
Louisiana & \\
Maine & \\
Maryland & \\
Massachusetts & \\
Mississippi & \\
New Brunswick & \\
New Hampshire & \\
New Jersey & \\
New York & \\
Newfoundland & \\
North Carolina & \\
Nova Scotia & \\
Quebec & \\
Quintana Roo & \\
Rhode Island & \\
South Carolina & \\
Tabasco & \\
Tamaulipas & \\
Texas & \\
Virginia & \\
Yucatan &
\end{tabular}


* Note the name has changed to Codium fragile spp. fragile, but we have used Codium fragile ssp. tomentosoides in our search given that this the term used in the literature.

Northern Europe

Location search terms Invasive species search terms

\begin{tabular}{ll}
\hline Belgium & Crassostrea gigas \\
Denmark & Mya arenaria \\
England & Mytilopsis leucophaeata \\
Estonia & Mytilus galloprovincialis \\
Finland & Sargassum muticum \\
Germany & Spartina alterniflora \\
Ireland & Urosalpinx cinerea \\
Latvia & \\
Lithuania & \\
Netherlands & \\
Norway & \\
Poland & \\
Scotland & \\
Sweden & \\
Wales & \\
& \\
Mediterranean Sea & \\
& Location search terms \\
Albania & \\
Algeria & \\
Bosnia and Herzegovina & \\
Croatia & \\
Cyprus & \\
Egypt & \\
France & Caulerpa \\
Greece & Crassostrea gigas \\
Israel & Mya arenaria \\
Libya & Sargassum muticum \\
Malta & \\
Monaco & \\
Montenegro & \\
Morocco & \\
\hline
\end{tabular}


Invasive species in marine reserves

Slovenia

Spain

Syria

Tunisia

Turkey 
Eastern Africa

Location search terms

Invasive species search terms

\begin{tabular}{|c|c|}
\hline Comoros & Carcinus maenas \\
\hline Kenya & Codium fragile ssp. tomentosoides \\
\hline Madagascar & Crassostrea gigas \\
\hline Mauritius & Kappaphycus spp \\
\hline Mayotte & Musculista senhousia \\
\hline Mozambique & Mytilus galloprovincialis \\
\hline \multicolumn{2}{|l|}{ Reunion } \\
\hline \multicolumn{2}{|l|}{ Seychelles } \\
\hline \multicolumn{2}{|l|}{ South Africa } \\
\hline \multicolumn{2}{|l|}{ Tanzania } \\
\hline \multicolumn{2}{|l|}{ Zanzibar } \\
\hline \multicolumn{2}{|l|}{ Africa } \\
\hline \multicolumn{2}{|l|}{ Asia } \\
\hline Location search terms & Invasive species search terms \\
\hline Bangladesh & Carcinus maenas \\
\hline Cambodia & Crassostrea gigas \\
\hline China & Kappaphycus spp. \\
\hline East Timor & Mytilopsis sallei \\
\hline Hong Kong & Ostrea edulis \\
\hline India & Spartina alterniflora \\
\hline Indonesia & Styela plicata \\
\hline \multicolumn{2}{|l|}{ Japan } \\
\hline \multicolumn{2}{|l|}{ Malaysia } \\
\hline \multicolumn{2}{|l|}{ Myanmar (Burma) } \\
\hline \multicolumn{2}{|l|}{ North Korea } \\
\hline \multicolumn{2}{|l|}{ Palau } \\
\hline \multicolumn{2}{|l|}{ Philippines } \\
\hline \multicolumn{2}{|l|}{ Singapore } \\
\hline \multicolumn{2}{|l|}{ South Korea } \\
\hline \multicolumn{2}{|l|}{ Sri Lanka } \\
\hline \multicolumn{2}{|l|}{ Taiwan } \\
\hline \multicolumn{2}{|l|}{ Thailand } \\
\hline Vietnam & \\
\hline
\end{tabular}


Australia

Location search terms

Invasive species search terms

\begin{tabular}{ll}
\hline Australia & Acanthogobius flavimanus \\
Queensland & Allita succinea \\
New South Wales & Ascidiella aspersa \\
Victoria & Asterias amurensis \\
Tasmania & Carcinus maenas \\
Northern Territory & Caulerpa taxifolia \\
& Codium fragile ssp. tomentosoides \\
& Crassostrea gigas \\
& Musculista senhousia \\
& Mya arenaria \\
& Mytilus galloprovincialis \\
& Ostrea edulis \\
& Perna viridis \\
& Sabella spallanzanii \\
& Spartina alterniflora \\
& Styela clava \\
& Styela plicata \\
& Undaria pinnatifida
\end{tabular}

New Zealand

Location search terms

Invasive species search terms

New Zealand

Charybdis japonica

Codium fragile ssp. tomentosoides

Crassostrea gigas

Musculista senhousia

Ostrea edulis

Spartina alterniflora

Styela clava

Undaria pinnatifida

Hawai'i

Location search terms

Invasive species search terms

Hawai'i

Acanthophora spicifera

Carijoa riisei

Chthamalus proteus

Gracilaria salicornia

Hypnea musciformis

Kappaphycus spp.

Lutjanus kasmira

Mycale grandis

Mytilus galloprovincialis 
South America

Location search terms

Argentina

Brazil

Chile

Colombia

Ecuador

French Guyana

Galapagos Islands

Guyana

Peru

Suriname

Uruguay

Venezuela
Invasive species search terms

Charybdis hellerii

Codium fragile ssp. tomentosoides

Crassostrea gigas

Geukensia demissa

Perna viridis

Rapana venosa

Tubastraea coccinea

Caribbean

Location search terms

Invasive species search terms

Anguilla

Antigua and Barbuda

Aruba

Barbados

Belize

British Virgin Islands

Caribbean

Cayman Islands

Costa Rica

Cuba

Dominica

Dominican Republic

Grenada

Guadeloupe

Guatemala

Honduras

Jamaica

Martinique

Montserrat

Netherlands Antilles

Nicaragua

Panama

Puerto Rico

Republic of Haiti
Charybdis hellerii

Halophila stipulacea

Perna viridis

Pterois volitans

Tubastraea coccinea 
St Kitts and Navis

St Lucia

St Vincent and the Grenadines

The Bahamas

Trinidad and Tobago

Turks and Caicos

Virgin Islands

West Indies 
Online Resource 3 - Notes on analysis and interpretation of case studies

\section{Halophila stipulacea (seagrass)}

Location: Anse la Raye Marine Reserve Management Area - St Lucia

Reference: Willette and Ambrose 2009, personal communication with author

\section{Comments:}

- H. stipulacea covered $50 \mathrm{~m}^{2}$ in total across 3 bays in St Lucia.

- The author reported via personal communication that Halophila stipulacea covered approximately $4 \mathrm{~m}^{2}$ the marine reserve

- Remaining $46 \mathrm{~m}^{2}$ of Halophila stipulacea occurred at two nearby non-reserve areas.

- Google Earth was used to measure the total area of the reserve and control areas, which then enabled calculation of the percent cover at each location.

\section{Nuttallia obscurata (bivalve)}

Location: Argyle Lagoon, British Camp Historical Site and Shaw Island - San Juan Islands, Washington, USA

Reference: Byers 2005

\section{Comments:}

- Reserves in San Juan Island permit limited recreational salmon (10 months/year, 2 fish/person/day) and herring fishing. Commercial harvest of salmon is prohibited.

- Study took place in intertidal areas, unlikely to be influenced by small amounts of fishing

- Fishing effort within reserves is minimal (Klinger personal communication)

\section{Carcinus maenas (crab)}

Location: Maria Island - Tasmania, Australia

Reference: Thresher et al. 2003

\section{Comments:}

- Since both reserve and control locations were present only in Tasmania, only this state was included in the analysis.

- Only locations along the east coast of Tasmania (excluding the Hobart area) were used as control locations

Table 2. Mean number of crabs per trap at sites on the east coast of Tasmania.

\begin{tabular}{|l|c|c|c|c|c|}
\hline Location & $\begin{array}{c}\text { Blackman } \\
\text { Bay }\end{array}$ & $\begin{array}{c}\text { Little } \\
\text { Swanport }\end{array}$ & $\begin{array}{c}\text { Henersons } \\
\text { Lagoon }\end{array}$ & $\begin{array}{c}\text { Maria } \\
\text { Island }\end{array}$ & $\begin{array}{c}\text { Georges } \\
\text { Bay }\end{array}$ \\
\hline Control & 1.1 & 22.5 & 43.7 & & 21.8 \\
\hline Reserve & & & & 10.6 & \\
\hline
\end{tabular}

\begin{tabular}{|l|l|l|l|l|l|l|}
\hline Unnamed control sites & 0 & 31.6 & 6.7 & 15.6 & 18 & 2 \\
\hline
\end{tabular}




\section{Carcinus maenas (crab)}

Location: Redwood Shores and Elkhorn Slough - California, USA

Reference: Grosholz and Ruiz 1995

Table 3. Average catch per trap of Carcinus in northern California.

\begin{tabular}{|l|l|l|}
\hline Location & Control & Reserves \\
\hline Eureka (Humboldt Bay) & 0 & \\
\hline Fort Bragg (Noyo River) & 0 & \\
\hline Gualala (Gualala River) & 0 & \\
\hline Salt Point (Gerstle Cove) & 0 & \\
\hline Bodega Harbor & 0.565 & \\
\hline Tomales Bay & 0.33 & \\
\hline Bolinas Lagoon (Kent Island) & 0 & \\
\hline Drakes Estero (Johnson Oyster) & 1.5 & 1 \\
\hline SF Bay (Redwood Shores) & & \\
\hline Pillar Point & 0 & 0 \\
\hline Monterey Bay (Elkhorn Slough) & & \\
\hline
\end{tabular}

\section{Undaria pinnatifida (alga)}

Location: Tinderbox - Tasmania, Australia

Reference: Barrett et al. 2009

Comments:

- Although Undaria has been present in Tasmania since 1988, it did not occur in Tinderbox Reserve or nearby control areas until spring 2001 (as determined from data within this paper).

- The mean percent cover of Undaria was averaged across 2 sites within the reserve and at 2 control sites.

\section{Chalinula nematifera (sponge)}

Location: Isla Isabel National Park and Cabo Pulmo - Mexico

\section{Reference: Avila and Carballo 2009}

\section{Comments:}

- The reserves have different levels of zoning, but the author confirmed that they sampled in no-take areas only.

\section{Undaria pinnatifida (alga)}

Location: Maria Island, Tasmania, Australia

Reference: Barrett et al. 2009

\section{Comments:}

- Undaria is an annual species with greatest biomass in spring (September); therefore we only included spring values in our analysis.

- Values were extracted from figures 
Table 4: Mean percent cover of Undaria averaged across replicate sampling sites within Maria Island Reserve and at control sites outside reserve.

\begin{tabular}{|l|c|c|c|c|c|c|}
\hline Year & 1992 & 1993 & 1997 & 1999 & 2000 & 2001 \\
\hline Control & 1 & 5.5 & 2 & 1 & 0.5 & 0.5 \\
\hline Reserve & 0 & 0.5 & 7 & 1.5 & 2.5 & 3 \\
\hline
\end{tabular}

\section{Mya arenaria (bivalve)}

Location: Argyle Lagoon, British Camp Historical Site and Shaw Island - San Juan Islands, Washington, USA

Reference: Byers 2005

\section{Comments:}

- For addition information on reserves see Nuttallia.

\section{Sargassum muticum (alga)}

Location: Point Caution, Point George, Yellow Island, Low Island, Argyle Lagoon and False Bay - San Juan Islands, USA

\section{Comments:}

- For addition information on reserves see Nuttallia.

\section{Crassostera gigas (bivalve)}

Location: Point Caution, Point George, Yellow Island, Low Island, Argyle Lagoon and False Bay - San Juan Islands, USA

Reference: Klinger et al. 2006

\section{Comments:}

- For addition information on reserves see Nuttallia.

\section{Venerupis philippinarum (bivalve)}

Location: Argyle Lagoon, British Camp Historical Site and Shaw Island - San Juan Islands, Washington, USA

Reference: Byers 2005

\section{Comments:}

- For addition information on reserves see Nuttallia.

\section{Elminius modestus (barnacle)}

Location: Lough Hyne Marine Nature Reserve - Ireland

Reference: Lawson et al 2004

\section{Comments:}

- No statistical comparison of densities inside and outside reserves was reported but the authors stated that "E. modestus was by far the most dominant species inside the Lough Hyne (reserve area) in terms of abundances at each site and distribution around the Lough."

- Values for average of maximum abundance we extracted from kite plots 